\title{
The Potential of Jack Bean (Canavalia ensiformis L.) Developed in Suboptimal Soil to Succeeding Food Sufficiency
}

\author{
Maria Theresia Darini ${ }^{1}$, Sri Endah P. Susilaningsih ${ }^{2}$, Yacobus Sunaryo ${ }^{3}$ \\ ${ }^{1,2,3}$ Agrotechnology Study Program, Faculty of Agriculture, Universitas Sarjanawiyata Tamansiswa Yogyakarta Indonesia
}

\begin{abstract}
The more population grows, the more the food demand required. In this case, soybean, due to the less production compared to rice. In order to support food self-sufficiency and soybean demands, tropical legumes are cultivated due to its nutritional content which is similar to soybean. The local Indonesian plant, jack bean has adaptive properties to sub-optimal land. It can adapt to various cultivation systems, high productivity, and similarity of nutritional content to soybean. It has quite unique adaptations which can grow its upright stems or grows vines, depends to the environment, and relatively shorter age than another type local bean plants. Jack bean seeds can be further processed into tempeh, powder, bakpia (Indonesian traditional sweet cake which using nuts for the filling), and various cakes as a substitute for soybean, mung bean, and wheat. Therefore, the jack bean plant has a great potential as food self-sufficient Indonesia's program.
\end{abstract}

KEYWORDS: High Production, Jack Bean, Nutritional Content.

\section{INTRODUCTION}

In 2015, Indonesia had 251 million populations, and it increased to 267 million in 2019. Based on a significant increase, it will increase to 3065 million people in 2035 [1]. The basic demand of the society is the food sufficiency, which Indonesian Government is currently working on. One of the crop that has potential as food sufficiency support is soybean. In 2013, soybean demand was about 2.20 million tons, sadly the local soybean only produced 789.992 million tons ( $33.9 \%$ of national demand).

Started in 2014, local soybean was produced until 954.997 million tons per year [2], 332 thousand tons soybean was produced outside Java (from 236 thousand hectares crop areas) and 622 thousand tons produced in Java (from a land area of 379 thousand hectares crop areas). Indonesia had imported soybean to fill the demand, and divided into 3 categories: for agriculture seed is 2.088 million tons, for food raw-source is 2.393 million tonnes, and soybean oil is 1.971 million tons.

The increasing demand for soybean is not proportionally suitable between land productivity and demands, it is necessary to find alternative commodities that have nutritional value as a soybean substitute. [3] reported that $92 \%$ of imported soybeans are processed by the tempeh (soybean fermented) industry. Based on Indonesian Law no. 18/2012 about Food and Its Regulations, the Government had a Program on Food Independency. This regulates the food self-sufficiency where the nation is able to produce diverse foods from within the country to fulfil the food demands. This program utilizes the potential of natural, human, socio-economic and local wisdom resources.

Local plants which have potential as a substitute for soybean are legume plants. Indonesia is rich in sources of biodiversity, which includes legumes, which have been cultivated as side crops or hedgerows. There is the local legumes plants which by Indonesian local people known as koro pedang (jack bean). The variants of the local legumes plant include the velvet bean, pegion bean, winged bean, lima bean and hyacinth bean. Jack bean has strengths, including: higher productivity, shorter lifespan, upright stems (shrubs), more resistant to biotic and abiotic environments [4]. However, the jack bean plant has the weakness, it contains toxic compounds: canavaline, choline, hydroziamine acid, trogonelin and cyanide. It can be removed through soaking and boiling process [5]. Jack bean has a tough pod skin. Therefore, during the food processing, it needs dry pod hitter, a seed coat peeler and a seed cutter, but currently there are electrical equipment that can simplify the processing of jack bean seeds.

For the development of jack bean, cultivation land and soil is required. However, the lands' function has changed drastically from agricultural land to non-agricultural land. Mostly, there are marginal lands or suboptimal land to cultivate the legumes with these new potentials. The utilization of this type of lands as urgent need requires strategic alternative to increasing agricultural products, reducing import demands, and succeeding national food selfsufficiency. Sub-optimal land area in Indonesia reaches 103.95 million ha, contains acid, rainfed, phosphorus deficiency, under-standing and swamps [6]. 


\section{International Journal of Current Science Research and Review}

ISSN: 2581-8341

Volume 04 Issue 07 July 2021

DOI: 10.47191/ijcsrr/V4-i7-17, Impact Factor: 5.825

IJCSRR@ 2021

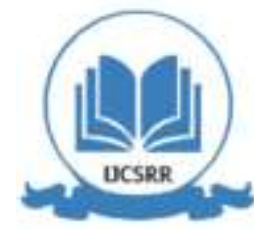

www.ijcsrr.org

[2] reported that the potential for sub-optimal land use for agriculture is very wide, 92.0 million hectares, so it is necessary to study and prepare technological innovations for the development of agricultural commodities, including various legumes. Likewise, in the Special Region of Yogyakarta for example, the lands functions changes from agricultural land to nonagriculture, reaching approximately 200 ha per year [7]. To restore the area of agricultural land with environmental conditions that suits the demands for crop cultivation, an effort to save natural resources through conservation is required. The availability of sub-optimal land is necessary for optimization efforts with the support of innovative technology to overcome land limiting factors [8].

Based on the description above, the cultivation of soybean substitute is required. In this case, jack bean has potential as substitution for self-sufficiency using local foods. The availability of jack bean can increase the diversity of food consumption and reduce dependence and food insecurity, especially soybean.

\section{POTENTIAL OF JACK BEAN (Canavalia ensiformis L.)}

The population and the level of welfare affect food demands, soybeans is one of them. Low soybean productivity causes increased demand and dependence on other countries on import. The types of the soybean plant that are easily available are legumes, because this plant is widely grown as a main or side crop, for example jack bean or locally known as Koro Pedang. There are 2 types of jack bean based on how they grow: upright and vine. The redseeded, which has English name Sword Bean grows as vine plant. Another types widely known as Jack Bean is white-seeded grows as upright plants [4]. Between the two types the alternative of white-seeded jack bean is a suitable choice.

The jack bean plant has long been known in Indonesia, because of its competitor plants, this plant is marginalized and not cultivated on a large scale. The jack bean plant is also drought tolerant and adaptive in acid dry land. This plant is can be cultivated in all types of soil, including sub-optimal soils. The technique of cultivating jack bean can be with monoculture and intercropping systems. For example, the cultivation of monoculture jack bean is carried out in Depok beach sand and Bugel beach sand lands [9]. The intercropping cultivation of intercropping jack bean, for example: cultivation along with chilies [10] and papaya in the sandy fields of Bugel and Garongan Kulonprogo [11].

The use of biotechnology has the potential to increase the production of food crops on marginal lands. To increase food productivity on marginal lands requires policy support and commitment from the government, both central and regional as well as farming communities [6].

[12] reported that the cultivation of jack bean reaches 4.53 tons per ha, as well as [13] reported that the treatment of plant by trimming the shoots and giving various concentrations of liquid organic fertilizer has a productivity of $3.9-4.6$ tons per ha. According to [14], the cultivation of jack bean in coastal sandy soil, which cultivated using spacing technique and chemical fertilizer production reaching 3.20 tons per ha. [5] reported that the potential yield of dry seeds reaches 12 tons and forage reaches $40-50$ tons per ha. The cultivation of jack bean in sub-optimal soil has been carried out in the sandy soils of Bantul and Kulonprogo Beach, Central Java. These cultivation were fertilized by various ameliorants from cow, chicken and goat manure, which produced 4.01 tons per ha $[15,16,17]$ reported that the cultivation of jack bean in marginal gromusol soil by fertilized ameliorant manure for cows, chickens, goats manure can produce 3.5 ton per ha.

[18] also reported that cultivation using spacing and cutting technique, it could reach 3.5 tonnes per ha, while [19] reported that the development of cultivation in lime land, through intercropping of jack bean plants with aloe vera plants can produced 2.20 tons per ha. Based on the productivity of the jack bean that has been carried out in various sub-optimal areas, the production can be categorized as higher than soybean.

Based on several reports, there are various variations in the nutritional content of jack bean, [20] reported that the nutritional content of jack bean seeds is $30.36 \%$ protein, $2.6 \%$ fat, $66 \%$ carbohydrates. The jack bean produced in Tanzania has $4.6 \%$ water content, $29.7 \%$ protein, $3.3 \%$ carbohydrate fat $53.9 \%$ and $3.4 \%$ ash [21]. [22] reports the following nutritional content of Nigerian jack bean, $14.39 \%$ water content, $34.47 \%$ protein, $4.09 \%$ fat, $42.13 \%$ carbohydrates, $5.86 \%$ fiber and $4.92 \%$ ash. The nutritional content of jack bean produced in India has $16.70 \%$ moisture, $2.21 \%$ reduction sugar, $3.41 \%$ total sugar, $0.19 \%$ acid, $10.85 \%$ proetin, $12.15 \%$ carbohydrates, 1 fat, $59 \mathrm{~g} / 100 \mathrm{~g}, 3.98 \mathrm{~g} / 100 \mathrm{~g}$ fibers and $8.087 \mathrm{~g} / 100 \mathrm{~g}$ vitamin C. Based on these nutritional content, jack bean are potential sources of protein, vitamins and energy supplements [23].

Due to the high of nutrition contents, the Yogyakarta Agricultural Technology Research Center (BPTP) together with the Faculty of Agriculture, Sarjanawiyata Tamansiswa University and the Regent of the Kulonprogo Regional Government have submitted 


\section{International Journal of Current Science Research and Review}

ISSN: 2581-8341

Volume 04 Issue 07 July 2021

DOI: 10.47191/ijesrr/V4-i7-17, Impact Factor: 5.825

IJCSRR@ 2021

WWw.ijesrr.org

registration for the local variety of jack bean with Letter No. 1165.1/PV.210/A9/10/2018. Then registration has been received by the Center for Plant Variety Protection and Agricultural Licensing with a Register of Plant Varieties, Local Varieties Number: 737/PVL/2018, dated 22 October 2018, with the name jack bean Bugel variety.

\section{OPPORTUNITIES FOR THE CULTIVATION}

Based on the characteristics of the jack bean including adaptability, nutritional content, productivity and cultivation system, this plant has an opportunity as a substitute for soybeans [5]. Various kinds of use of the jack bean as a material substitution include:

a. Soybean substitution, according to the report of [24] that Tempeh made from jack bean has similar taste to soybean Tempeh. The have similar color, aroma, texture, acidity and accepted well by the market. [25] reported that jack bean is suitable as a raw material for business/industrial Tempeh therefore it has prospective market opportunities and competitive.

b. The meal substitution, [26] reported that jack bean flour can substitute $50 \%$ of soybean which later used as chicken broiler feed 35 days. The feed substitution considered successful since the chicken meat production did not change its appearance, carcass production, commercial cuts, internal organ weight and organ immunity and blood profile.

c. Wheat substitution, [27] reported that the taste and texture of brownies made using jack bean flour has $100 \%$ similarity from brownies made with $100 \%$ wheat flour.

However, jack bean flour is $80 \%$ more expensive.

Other benefits of the jack bean:

a. Forage, [28] reported that the jack bean can be used as forage.

b. Processed foods, [29] reported that jack bean seeds are processed into various foods. It can be roasted or fermented to maintain a nutritional balance.

c. Biopesticides, [30] reported that the content of the urease enzyme from the jack bean has antifungal and antibacterial properties towards plants and animals. [31] [32] reported that jack bean seeds contain urease enzyme called jack bean urease (JBU) which can act as a natural insecticide.

d. Anti-cholesterol herbs, [33] reported that giving jack bean seed milk to white mice for 14 days can reduce LDL cholesterol levels, but not increase HDL levels.

e. Anticancer, Canavanine have the potential property to improve cancer healing by irradiation [34], as well as [35] reported based on their research results Canavanine has the potential to treat cancer.

There are still other benefits of jack bean applied by the society but have not been studied scientifically.

\section{SUGGESTIONS}

The white-seeded jack bean has high potential and opportunity to be cultivated as foodsufficiency program and substitute the soybean due to high demand. This requires the supports and policies of all parties: Government, Organizations, Local Governments, farmers, and the society. The cultivation of jack bean needs these following steps:

1. Increase production by increasing cultivation areas.

2. Improving quality by using biological fertilizers.

3. Creation and distribution of equipment to facilitate processing.

4. Training related to the cultivation and improvement of jack bean for Small Medium Enterprises, industrial groups, and farmers to increase the knowledge of the cultivation and quality.

5. Capital assistance to Small Medium Enterprises and the farmers

6. Establishing the jack bean agroindustry

7. Socialization of processed and marketing products based on jack bean to the society.

\section{REFERENCES}

1. Statistical Center Institute. 2019. Statistical Yearbook of Indonesia.

2. Harnowo, D. 2014. National soybean production is still low. Proceedings of the National Seminar on Soybean Agribusiness. Between Self-Sufficiency and Welfare of farmers. Faculty of Agriculture Universitas Gadjah Mada Yogyakarta, May 14, 2014. 


\section{International Journal of Current Science Research and Review}

ISSN: 2581-8341

Volume 04 Issue 07 July 2021

DOI: 10.47191/ijesrr/V4-i7-17, Impact Factor: 5.825

IJCSRR@ 2021

WwW.ijcsrr.org

3. Kunjana, G. 2018. Nine-two percent of imports are absorbed by the tempe industry. gorakunjana@investor.co.id

4. Darini, M.Th. dan Kusdiarti L. 2017. Growth and yield of jack bean (Canavalia ensiformis L.) seeds on inoculation of various Rhizobium and urea dosage in sandy soil. J. Agroista Agroteknologi, 01 (2): 113-122.

5. Kasno, A. 2016. Jack bean (Canavalia Sp.) Forgotten Multipurpose Commodity. Research Institute for Nuts and Tubers. BPPP Ministry of Agriculture, Science Intern, Network, www.litbang.deptan.go.id

6. Suyanto, P. 2012. The role of biotechnology for increasing food products on marginal Land. J. Food 21(1): $101-111$.

7. Yanti, G. I., E. Martono, dan S. Subejo, S. 2016. Protection of sustainable food agricultural land in order to strengthen food security in the district of Bantul Specially Region of Yogyakarta. J. Succeeding Food, 22(1): 1 - 21.

8. Maswar. 2017. Research on Sub-optimal Land Management and Degraded Land to Support Increased Productivity of Food Crops and Horticulture. Agricultural Research and Development Agency, Ministry of Agriculture.

9. Faculty of Agriculture UST Team. 2016. The development of the jack bean plant in the coastal sandy area of Depok, Parangtritis District, Bantul Community Development Program, BNI 46 Bank.

10. Faculty of Agriculture UST Team. 2017. Development of jack bean through intercropping with chili plants in Bugel and Garongan villages, Kulonprogo. BNI 46 Community Development Program.

11. Faculty of Agriculture UST Team. 2018. Development of jack bean through intercropping with papaya plants in Bugel and Garongan villages, Kulonprogo. BNI 46 Community Development Program.

12. Sheahan, C. M. 2013. Plant guide for jackbean (Canavalia ensiformis L. DC). USDA Natural Resources Conservation Service, Cape may Plant materials Center Cape May NJ. http://plant.usda.gov/plant guide/pdf/pg-cape 4.pdf.

13. Usman, I. Rahim, A.A. Ambar, 2013. Analysis growth and production of world of jack bean (Canavalia ensiformis L.) in various concentration of organic liquid fertilizer and pruning. J. Galung Tropika, 2(2): 85 - 96.

14. Darnawi dan Darini M. Th. 2016. Agronomic character of jack bean (Canavalia ensiformis L.) at various spacings and ratios of chemical fertilizers in sandy soil. J. Techno- Science, LPPM UST, 1(1): 12 - 18.

15. Prasetyowati, E.S. and Y. Sunaryo, 2017. Effect of organic manure on growth and yield of jack bean (Canavalia ensiformis L.) in coastal sandy and grumosol soil. Int. J. Adv. Enginn. and Technol. 5 (3-2): 64 - 67, http://iraj.in

16. Prasetyowati, E.S. dan Y. Sunaryo, 2018. Effect of organic fertilizer and tillage depth on growth and yield of jack bean (Canavalia ensiformis L.) on marginal land of grumosol soil. J. Agriculture Sci. Agros, 20 (1): 16 - 21. Email: agrosujb/yahoo.com.sg

17. Prasetyowati, E.S., Y. Sunaryo dan I. E. Suyanto, 2018. Effect of types of ameliorant and biofertiliser on growth and yield of jack bean in marginal land of grumosol soil J. Agric. Sci. Agros, 21 (1): 129 - 135. Email: agrosujb/yahoo.com.sg

18. Sarijan, A., M. Surahman, A. Setiawan, Giyanto, 2018. Pruning, cropping pattern and spacing regulation to enhance growth, production and seed quality of jackbean (Canavalia ensiformis L.). Int. J. Agron. Agric. Res. 12 (1): 46 - 52 http://www. innspub.nett

19. Darini, M. Th., A. Astuti and Zamroni. 2020. Correlation between nodul population with agronomic character of jack bean (Canavalia ensiformis L) intercropping Aloe vera L. plant in the calcareus soil, Int. J. Adv. Sci. Inform. Technol, accepted April, 2020

20. Wardani, D.M. 2016. The jack bean alternative material for making tempeh. http://www. satuharapan.com.

21. Karoli, N., Sumari J.O. and Marealle, H. 2017. Utilization of jack beans (Canavalia ensiformis) for human consumption in Tanzania. Int. J. Agric. and Food Security ISSN: 0812-3497 3 (3): 039-049, http://www.advancedscholarsjournals.org.

22. Nimenibo-Uadia, R.I. 2017. Preliminary studies on Canavalia ensiformis (Jack Bean) DC seeds: Proximate Analysis and phytochemical screning. Sci. World J. 12 (2): 59 - 62. http://www.scienceworldjournal.org

23. Patel, R., Singh, R.K.R., Tyagi, V., Mallesha and Raju, P.S. 2016. Nutritional evaluation of Canavalia ensiformis L. (jackbean) in north East region India. Int. J. Botany Studies 1 (6): 18 - 21. http://www.Botanyjournals.com

24. Widaningrum, E. Sukasih and Y. Purwani, 2015. Introduction study on processing of fermented jack bean (Canavalia ensiformis L.). J. Penelitian Pascapanen Pertanian, 12 (3): 129 - 136. DOI. 10. 21082/jpasca.v12n3.2015.129.136.

25. Indah, $\mathrm{N}$ dan Susilo, D.K. 2016. Jack bean agribusiness opportunities as raw material substitute for soybeans for the tempe industry in Jember Regency. Agritrop Jurnal Ilmu-Ilmu Pertanian, 121-125. 


\section{International Journal of Current Science Research and Review}

ISSN: 2581-8341

Volume 04 Issue 07 July 2021

DOI: 10.47191/ijesrr/V4-i7-17, Impact Factor: 5.825

IJCSRR@ 2021

www.ijesrr.org

26. Jayanti, A. M., Sudarman, Mutia, A. dan Rita. 2017. Utilization of swordfish (Canavalia ensiformis) as a substitute for soybean meal for broiler rations. Repository Institut Pertanian Bogor. http://repository.ipb.ac.id/handel/123456789/88671.

27. Wahjuningsih, S.B. dan W. Saddewisasi, 2014. Utilization of the jack bean in product applications and economic analysis. Riptek 7 (2): 1- 10, http://www.bappeda.semarangkota.go.id.

28. Indriani, N.P., Mustafa, H.K. dan Ayuningsih, B. 2017. The introduction of the jack bean plant (Canavalia ensiformis L.) as forage inoculated mycorrhizae in Jatiroke village. J. Pengabdian Masyarakat 1(4): 262 - 265.

29. Michael, K.G., Sogbesan, O.A. and Onyia, L.U. 2018. Effect of processing methods on the nutrtional value of Canavalia ensiformis L jack bean seed meal. J. Food Processing \& Technol. 9 (12): 1 - 5, DOI. 10.4172/2157-7110.1000766.

30. Postal, M., A. H. S. Martinelli, A.B. Backer-Ritt, R. Ligabue- Braun, D. R. Demartini, S. F. F. Riberio, G. Pasquali, V. M. Gomes and C. R. Carlini, 2012. Antifungal properties of Canavalia ensiformis L. Urease and derived peptidies. Peptides J. 38 (1): 22 - 32, PMID. 22922160, DOI. 10.1016/j.peptides.2012.08.010.

31. Real - Guerra, R., C. R. Carlini and F. Stanisquaski, 2013. Role of lysine and acidic amino acid residues on the insecticidal activity of jack bean urease. J. Toxicon, 71: 76 - 83, PMID. 23726854, DOI. 10.1016/j.toxicon.2013.05.008

32. Micheletto, Y.M.S., Moro, C.F., Lopes, F.C., Ligabue-Braun, L., Martinelli, H.S., Marques,C.M., Schroder, A.P., Carlini C.R. and Silveira, N.P. 2016. Interaction of jack bean (Canavalia ensiformis L.) urease and a derived peptide with lipid vesicles. Colloids surf B. Biointerfaces, 145: 576 - 585, PMID. 27281243, DOI. 10.1016/j.colsurfb.2016.05.063.

33. Naufalina, M. D. dan Nuryanto. 2014. Effect of giving jack bean milk (Canavalia ensiformis L.) on LDL and HDL cholesterol levels in dyslipedia rats. J. Nutrtion Coll, 3 (4): 456 - 464, http://ejournal.se.undip.ac.id/index.php/jne

34. Vynnytska - Myronovska, B. S., Y. Bobak, Y. Garbe, C. Dittfed, O. Stasyk and L.A. Kunz-Schughart, 2012. Single aminoacid arginie starvation efficiently sensities cancer cells to canavanine treatment and irradiation. Int. J. Cancer, 130 (9): 2164 - 2175. http://doi.org/10.1002/ijc.26221.

35. Nurcahyanti, A. D. R. and Wink, M. 2017. L. Canavanine potenties cytotoxicity of chemotherapeutic drugs in human breast cancer cells. Anticancer Agent Med. Chem. 17 (2): 206 - 2011. DOI. 10.2174/18715206.

Cite this Article: Maria Theresia Darini, Sri Endah P. Susilaningsih, Yacobus Sunaryo (2021). The Potential of Jack Bean (Canavalia ensiformis L.) Developed in Suboptimal Soil to Succeeding Food Sufficiency. International Journal of Current Science Research and Review, 4(7), 740-744 